Review

\title{
The Pivotal Role of Thymus in Atherosclerosis Mediated by Immune and Inflammatory Response
}

\author{
Xianliang Dai ${ }^{1,2^{*}}$, Danfeng Zhang $3^{3^{*}}$, Chaoqun Wang ${ }^{4,5^{*}}$, Zonggui $\mathrm{Wu}{ }^{1 凶}$, Chun Liang ${ }^{\bowtie}$ \\ 1. Department of Cardiology, Changzheng Hospital, Second Military Medical University, Shanghai 200003, China; \\ 2. Department of Cardiology, 101 Hospital of PLA, Wuxi, Jiangsu province 214041, China; \\ 3. Department of Neurosurgery, Changzheng Hospital, Second Military Medical University, Shanghai 200003, China; \\ 4. Department of Endocrinology, Changzheng Hospital, Second Military Medical University, Shanghai 200003, China; \\ 5. Department of Endocrinology, Changhai Hospital, Second Military Medical University, Shanghai 200003, China. \\ * These authors have contributed equally to this work
}

$\square$ Corresponding author: Department of Cardiology, Shanghai Changzheng Hospital, Second Military Medical University. No. 415 Fengyang Road, Shanghai 200003, People's Republic of China. Tel: +86-021-81885302 Fax: +86-021-63520020. E-mail address: chunliang@smmu.edu.cn or zongguiwu@smmu.edu.cn

(c) Ivyspring International Publisher. This is an open access article distributed under the terms of the Creative Commons Attribution (CC BY-NC) license (https:// creativecommons.org/licenses/by-nc/4.0/). See http://ivyspring.com/terms for full terms and conditions.

Received: 2018.05.14; Accepted: 2018.09.06; Published: 2018.10.20

\begin{abstract}
Atherosclerosis is one kind of chronic inflammatory disease, in which multiple types of immune cells or factors are involved. Data from experimental and clinical studies on atherosclerosis have confirmed the key roles of immune cells and inflammation in such process. The thymus as a key organ in T lymphocyte ontogenesis has an important role in optimizing immune system function throughout the life, and dysfunction of thymus has been proved to be associated with severity of atherosclerosis. Based on previous research, we begin with the hypothesis that low density lipoprotein or cholesterol reduces the expression of the thymus transcription factor Foxnl via low density lipoprotein receptors on the membrane surface and low density lipoprotein receptor related proteins on the cell surface, which cause the thymus function decline or degradation. The imbalance of $T$ cell subgroups and the decrease of naive $T$ cells due to thymus dysfunction cause the increase or decrease in the secretion of various inflammatory factors, which in turn aggravates or inhibits atherosclerosis progression and cardiovascular events. Hence, thymus may be the pivotal role in coronary heart disease mediated by atherosclerosis and cardiovascular events and it can imply a novel treatment strategy for the clinical management of patients with atherosclerosis in addition to different commercial drugs. Modulation of immune system by inducing thymus function may be a therapeutic approach for the prevention of atherosclerosis. Purpose of this review is to summarize and discuss the recent advances about the impact of thymus function on atherosclerosis by the data from animal or human studies and the potential mechanisms.
\end{abstract}

Key words: atherosclerosis, thymus, aging, inflammatory, immune, mechanisms, Foxn1

\section{Introduction}

Atherosclerosis is a complex disease, in which multiple types of immune cells, inflammatory cells and cytokines are involved[1-8] (Fig. 1). Lipid metabolism is the pathological basis of atherosclerosis, which is characterized by involvement of artery lesions from the intima, usually the formation of lipid and compound carbohydrate accumulation, bleeding and thrombosis at first, and hyperplasia of fibrous tissue and calcium deposition, and has gradually degenerated and medial calcification, leading to arterial wall thickening and hardening, vascular stenosis. That increases the incidence and mortality of patients with heart and cerebrovascular disease. So to reduce the incidence and mortality of heart and cerebrovascular disease in patients with coronary heart disease is the ultimate goal of anti-atherosclerosis therapy. Therefore, it is of great clinical and practical significance to study the mechanism of atherosclerosis.

Epidemiological studies have shown that the higher the incidence of atherosclerosis with age, the higher prevalence is mainly in middle-aged and elderly patients. The immune system function of elderly patients decreased, the number of immune 
cells decreased, and the proportion was imbalanced. Previous studies have shown that a series of immune cells and their secreted cytokines are involved in the process of atherosclerosis, especially $\mathrm{T}$ lymphocytes. According to previous studies, the thymus will be shrunk with age, and may even disappear. However, with the deepening of the research in recent years, the researchers found that although thymus may deteriorate with age, it will not disappear and still has a certain function. A recent article by Sam Palmer et al. published in PNAS reveals that the vast majority of vertebrates will experience thymic involution (or atrophy) in which thymic epithelial tissue is replaced with adipose tissue, and result in decreasing export of $\mathrm{T}$ cell from the thymus[9]. John Murray et al. clearly stated the thymus continued to provide a source of new $\mathrm{T}$ lymphocytes through all ages in their research[10]. More importantly, Lynch et al also provided a relatively detailed description of age-related thymus atrophy, in which the authors also recalled that based on their and other previous investigators' results, the thymus would completely cease to produce new $\mathrm{T}$ cells at 105 years of age[11]. The thymus as a key organ in $\mathrm{T}$ lymphocyte ontogenesis plays an important role in optimizing immune system function throughout the life[12, 13]. Studies have revealed that thymus is constantly atrophic or hypofunction with age[14]. The thymus is most active early in life but undergoes a steady decline in function over time[15-18]. Those age-associated immune dysfunctions are the consequence of declines in both the generation of new naïve $\mathrm{T}$ and $\mathrm{B}$ lymphocytes and the functional competence of memory populations[15]. Thymus transplantation can alter or partially reverse some immune related diseases, such as Alzheimer's disease, systemic lupus erythematosus, arthritis, etc[19-22]. It is well known that atherosclerosis is also an immune related disease[23-25]. So atherosclerosis should have a close relationship with thymus.

Our previous study showed that there was a decline in thymus function in atherosclerotic patients[26]. Therefore, the thymus may be involved in the process of atherosclerosis. However, the mechanism of thymus function involved in the process of atherosclerosis is still unclear. The purpose of this review is to summarize and discuss the recent advances in our knowledge of atherosclerosis vascular disease by the impact of thymus function on atherosclerosis, especially for the mechanism.
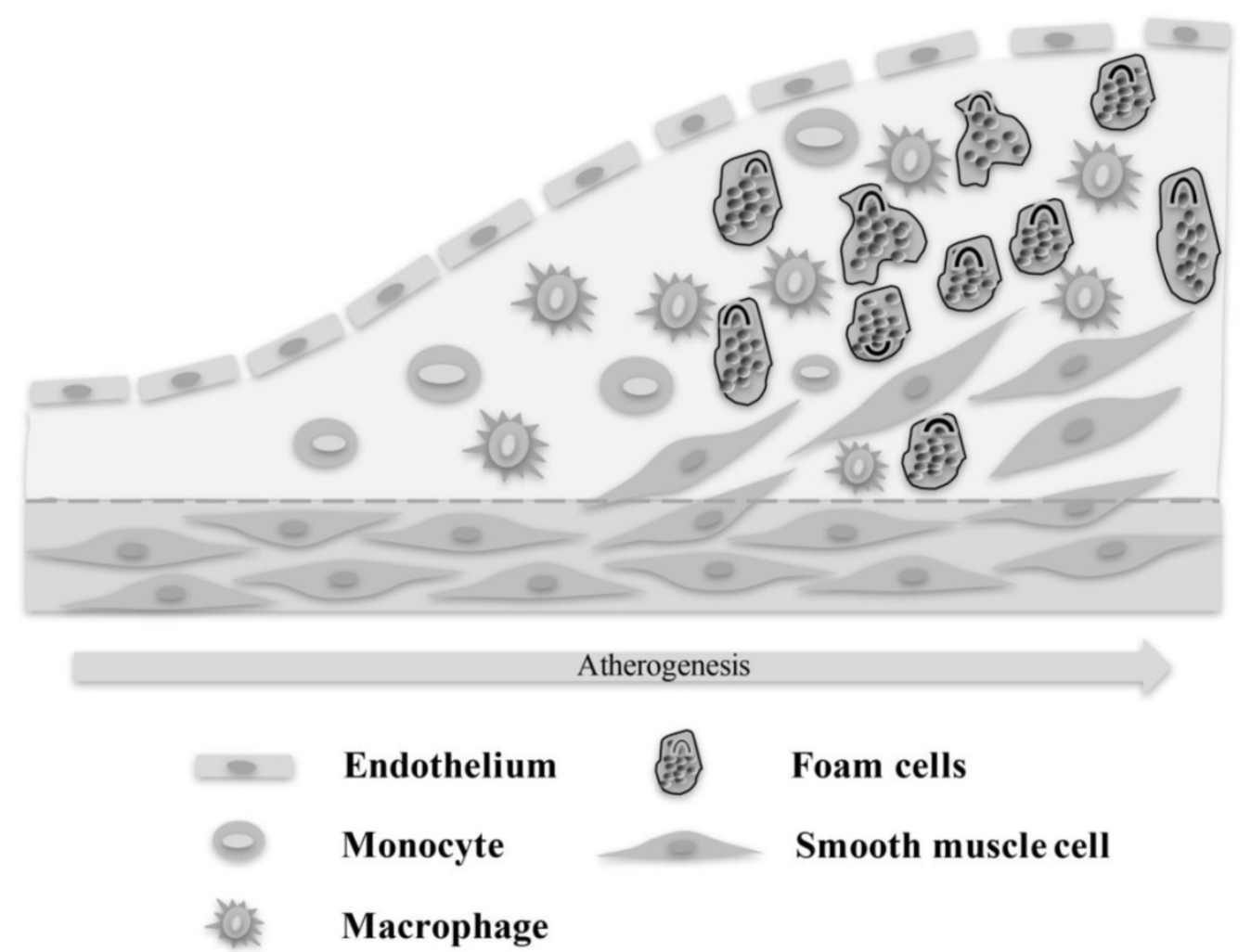

Figure 1. Immune cells including macrophages, T cells and monocyte are involved in the process of blood vessels from normal to atherosclerosis. 


\section{Thymus can directly or indirectly modulate inflammatory procedure}

Thymus is an important part for $\mathrm{T}$ cell development and maturation. Indeed, the thymus is both where the $\mathrm{T}$ cell repertoire is generated and where the $\mathrm{T}$ cells are composed of positive and negative selection, leading to a wide range of functional MHC-restricted naïve TCR $\alpha \beta$ repertoire[27, 28]. As the development of $\mathrm{T}$ cells, they migrate within distinct thymus microenvironments, where they interact with stromal cells that provide signals critical for thymocyte survival, proliferation, differentiation, and selection[29-31].

$\mathrm{T}$ cells contain many subgroups. A brief introduction of $\mathrm{T}$ cell subgroups and their functions shows as follow. Naive $\mathrm{T}$ cells can differentiate into helper $\mathrm{T}$ cells(Th), regulatory $\mathrm{T}$ cells(Tregs) and cytotoxic $\mathrm{T}$ cells $(\mathrm{Tc})$. The generation and maturation of this specific $\mathrm{T}$ cell lineage involve particular and complex processes within the thymus, and many signaling pathways participate in these processes. If a thymocyte is auto-reactive against antigens, it undergoes negative selection, via apoptosis, or differentiation into the regulatory $\mathrm{T}$ cell lineage. It is now well established that there are two main pathways for the generation of Treg cells in vivo. The majority of functionally mature Treg cells are produced in the thymus, where recognition of self-antigen by certain clones leads to their deviation into the thymus-derived Foxp3+ Treg (tTreg) cell lineage[32, 33]. Th can secrete IL-4, IL-17, and IFN-Y. In addition, Tregs can secrete IL-10. IL-4, a cytokine that stimulates the proliferation of activated B-cells and mast cells and enhances macrophages antigen presenting ability. In the absence of vascular tissue, the presence of IL 4 promotes the substitution of activated macrophages into M2 cells and inhibits the activation of classical activated macrophage M1 cells. Increased macrophage repair (M2) combined with the secretion of IL-10 and TGF- $\beta$ resulted in a reduction of pathological inflammation[34-36]. The most compelling role of IL-17 is its involvement in the induction and regulation of pro-inflammatory responses. IL-17 induced production of other cytokines (e.g., IL-6, G-CSF, TGF- $\beta$, TNF- $\alpha$, GM-CSF and IL-1 $\beta$ ), chemokines (including IL-8, GRO- $\alpha$, MCP-1) and prostaglandin (e.g., $\mathrm{PGE}_{2}$ ) from many types of cells, such as fibroblasts, endothelial cells, epithelial cells, keratinocytes and macrophages [37-41].

All of these cytokines, chemokines, and inflammatory cells are involved in the inflammatory procedure and atherosclerosis[42, 43]. Previous studies have shown that some cytokines(such as
TNF-a, IL-1,8,12 and IFN- $\gamma$ etc.) promote the occurrence of atherosclerosis[44-65], while others(such as TNF- $\beta$, IL-4 and IL-10 etc.) inhibit the process of atherosclerosis [1, 61, 66-75] (see Table 1). Studies show that IL-6 can support a promotion and inhibition role in the development of atherosclerosis[76-78]. Besides, cytokine therapy with IL-2/anti-IL-2 monoclonal antibody complexes can attenuate the development and progression of atherosclerosis[79-81]. In summary, we learn that the thymus can directly or indirectly affect the above factors or cells, which may affect the atherosclerotic process. Thus, alterations in thymus function may be involved in atherogenesis by modulating inflammatory responses.

Table 1. Cytokines can promote or inhibit atherosclerosis

\begin{tabular}{lll}
\hline Cytokines & $\begin{array}{l}\text { Whether it promotes or } \\
\text { inhibits atherosclerosis? }\end{array}$ & References \\
\hline TNF- $\alpha$ & Promotion & Refs: $40-46$ \\
TNF- $\beta$ & Inhibition & Refs: $1,62-65$ \\
IL-1 & Promotion & Refs: $47-49$ \\
IL-4 & Inhibition & Refs: $57,66,67$ \\
IL-6 & Promotion/ Inhibition & Refs: $72-74$ \\
IL-8 & Promotion & Refs: $50-54$ \\
IL-10 & Inhibition & Refs: $62,68-71$ \\
IL-12 & Promotion & Refs: $55-58$ \\
IFN- $\gamma$ & Promotion & Refs: $59-61$ \\
\hline
\end{tabular}

Refs stand for References.

\section{Thymus may regulate the immune system by affecting immune cells}

The thymus is a privileged and indispensable site for the generation and maturation of $\mathrm{T}$ cells in vivo, as this microenvironment induces and supports lineage commitment, differentiation, and survival of thymus-seeding cells. Tregs selection in the thymus is essential to prevent autoimmune diseases[82]. Tregs of the CD4+CD25+FOXP3+ phenotype are generated in the thymus and critical for the maintenance of immune homeostasis and the suppression of naturally occurring self-reactive T cells[83-85].

According to the previous researches, we should learn that the change of thymus function can affect the function of macrophages and $B$ cells. The monocyte-macrophage system has a crucial role in innate immunity and also in the initiation of the adaptive immune response[86-88]. Plasma cells derived from $B$ cells participate in humoral immune response. Moreover, dendritic cells(DCs) play a significant role in establishing self-tolerance and inducing antigen-specific immunity through their ability to present self-antigens to developing $\mathrm{T}$ cells in the thymus[89-91]. These cells are involved in the immune response. Hence, changes of the thymus 
function can affect the immune system.

Atherosclerosis is a complex disease characterized by smooth muscle cell proliferation, cholesterol deposition, and the infiltration of mononuclear cells. The formation and progression of atherosclerotic plaques result in the disruption of organ perfusion, causing cardiovascular and cerebrovascular diseases. It has been proved that immune responses participate in every phase of atherosclerosis. The presence of leukocytes within atherosclerotic arteries was discovered in the late 1970s[2, 92]. There is increasing evidence show that both adaptive and innate immunity tightly regulate the development and progression of atherosclerosis.

Recent studies have suggested that Tregs, a special $\mathrm{T}$ cell subtype, exhibit a weak immune response, have immune-suppressive characteristics of immune-related vascular disease, and play an important role in immune tolerance and immune regulation[1, 2, 93-98]. What was discovered in recent years is that several subsets of Tregs, which are responsible for maintenance of immunological tolerance and suppressing immune over activity of effector T cells, diminish atherosclerosis development by down-regulation of activated $\mathrm{T}$ cell responses[99-103]. There are more and more evidences show that $\mathrm{CD}^{+}$effector $\mathrm{T}$ cells may accelerate the development of atherosclerosis. In contrast, $\mathrm{CD}^{+}{ }^{+}$Treg cells play a protective role in atherosclerosis[42, 97, 102, 104-108]. During the occurrence and development of atherosclerosis, diverse types of interactions between immune cells, cytokines, and antibodies form a very complex network of cellular and humoral immune mechanisms[108-110]. Indeed, once Tregs are activated, they can secrete IL-10 and TGF- $\beta 1$ to suppress several cell types, including antigen-specific T cells[66-69, 96]. Besides the balance between effector $\mathrm{T}$ cells and Tregs, which is sufficient to control atherosclerosis development and progression[111-118]. Tregs inhibit the activation of other lymphocytes via the direct secretion of cytokines or inducing other cells to secrete cytokines, hereby limiting the occurrence and development of atherosclerosis[74, 75]. In addition to Tregs, tolerogenic DCs have a critical role in the regulation of $\mathrm{T}$ cell response in atherosclerosis according to previous research[119-123].

In a word, changes in thymus function may take part in atherogenesis by regulating the immune system.

\section{Aging and atherosclerosis}

Aging, which many aspects of that involve inflammatory processes, is associated with chronic, low-grade inflammatory activity leading to long-term tissue damage, and systemic chronic inflammation has been found to be related to all-cause mortality risk in elderly persons[124-129]. Age-related diseases such as Alzheimer's disease, Parkinson's disease, atherosclerosis, and type 2 diabetes are initiated or worsened by systemic inflammation, because the genetic constitution of the organism interacting with systemic inflammation may cause defined organ-specific illnesses, thus suggesting the critical importance of unregulated systemic inflammation in the shortening of survival in humans.

Thymus is an aging associated organ. But evidences have shown that the processes of positive and negative selection qualitatively appear to remain intact, despite the quantitative reductions in cortical and medullary thymocytes in the aged thymus[16-18, 130-134]. Moreover, the naive $\mathrm{T}$ cells generated in aged mice appear functionally normal but the decrease in thymic productivity[135, 136]. Increasing the input of functional thymus progenitors can trigger an expansion of thymus epithelial cells (TEC), which in turn create new niches for T-cell lineage commitment and supports increased the proliferation of thymocyte. Alternatively, in aging, the decline in these factors may reinforce a down-ward spiral resulting in thymic involution.

The thymus is the main immune organ and capable of generating $\mathrm{T}$ cells throughout life and is crucial for development, selection, and maintenance of peripheral T-cells. It is well documented that aging negatively affects immune responses, leading to an increase in infection and mortality. Aging reduces immune function, part of the reason is thymus involution leads to striking loss of progenitors, epithelial cells, and differentiating thymocytes, causing a decline in the production of naive $\mathrm{T}$ cells by the thymus[18, 137-142].

Thymus transcription factors forkhead box N1(Foxn1) is the most important factor for thymus complete physiological function[141, 143-145]. With the atrophy of thymus, the expression of thymus aging-associated gene Foxn1 decreases, that means down-regulation of Foxn1 with age. Increased expression of Foxn1 can improve thymus function, and even promote regeneration of the thymus [146]. Žuklys S et al.[147] determine that Foxn1 regulates the expression of genes involved in antigen processing and thymocyte selection, in addition to the transcriptional control of genes involved in the attraction and lineage commitment of $\mathrm{T}$ cell precursors. Therefore, there are reasons to believe that the thymus Foxn1 may be involved in the process of atherosclerosis. In previous studies, the atrophy of thymus organs in patients with coronary heart disease 
has been confirmed[26], yet the specific altering of thymus function has not been clearly revealed.

Lipid metabolism is the pathological basis of atherosclerosis. Low density lipoprotein(LDL) in the arterial wall is generally oxidized to oxidized LDL (oxLDL), which is atherogenic, and induces vascular endothelial cells to express adhesion molecules, cytokines and chemokines that attract immune cells[5, 148-152]. Amy H. Newton et al.[148] found that naïve cells become activated and differentiate to mature effector T cells that are Th1, Th2 or Treg cells. OxLDL and high density lipoprotein (HDL) regulate activation of macrophages and endothelial cells, and T cells, which perpetuate atherogenesis by promoting cell-mediated responses and inflammation. OxLDL leads to inflammation and nucleation of atherosclerotic plaque in the arterial wall and its incorporation into foam cells, which is opposed by HDL.

LDL receptor-related protein-1 (LRP-1), a member of the scavenger receptor family, is a large endocytic receptor and is a multifunctional cell surface receptor expressed in a wide range of cells, including vascular smooth muscle cells(vSMCs) and macrophages[153-156]. The early studies have revealed that mice with a selective knockout of LRP in macrophages crossed into an apoE/LDL receptor double knockout mouse[157-160] or vSMCs (LRPsmc-/-) on an LDL receptor (LDLR) ${ }^{-/-}$background lead to an exacerbation of atherosclerosis[161-163]. LRP-1 plays a role in arterial wall physiology and pathology[159, 160, 164-166]. From the study of Kamel Boukais et al., we know that LRP-1 is also a scavenger receptor responsible for the uptake of LDL, especially the aggregation of LDL, leading to intracellular accumulation of lipids and transformation of vSMCs and monocyte-derived macrophages into foam cells in human atheroma[154, 161, 167-169]. Although LDL remains to be the most important risk factor for atherosclerosis, immune and inflammatory mechanisms play a significant and non-redundant role in atherogenesis.

Based on the above statement, we propose the hypothesis of the mechanism of thymic function to participate in the process of atherosclerosis (Fig. 2). Hence, the change of thymus function provides a new target for the treatment of atherosclerosis.

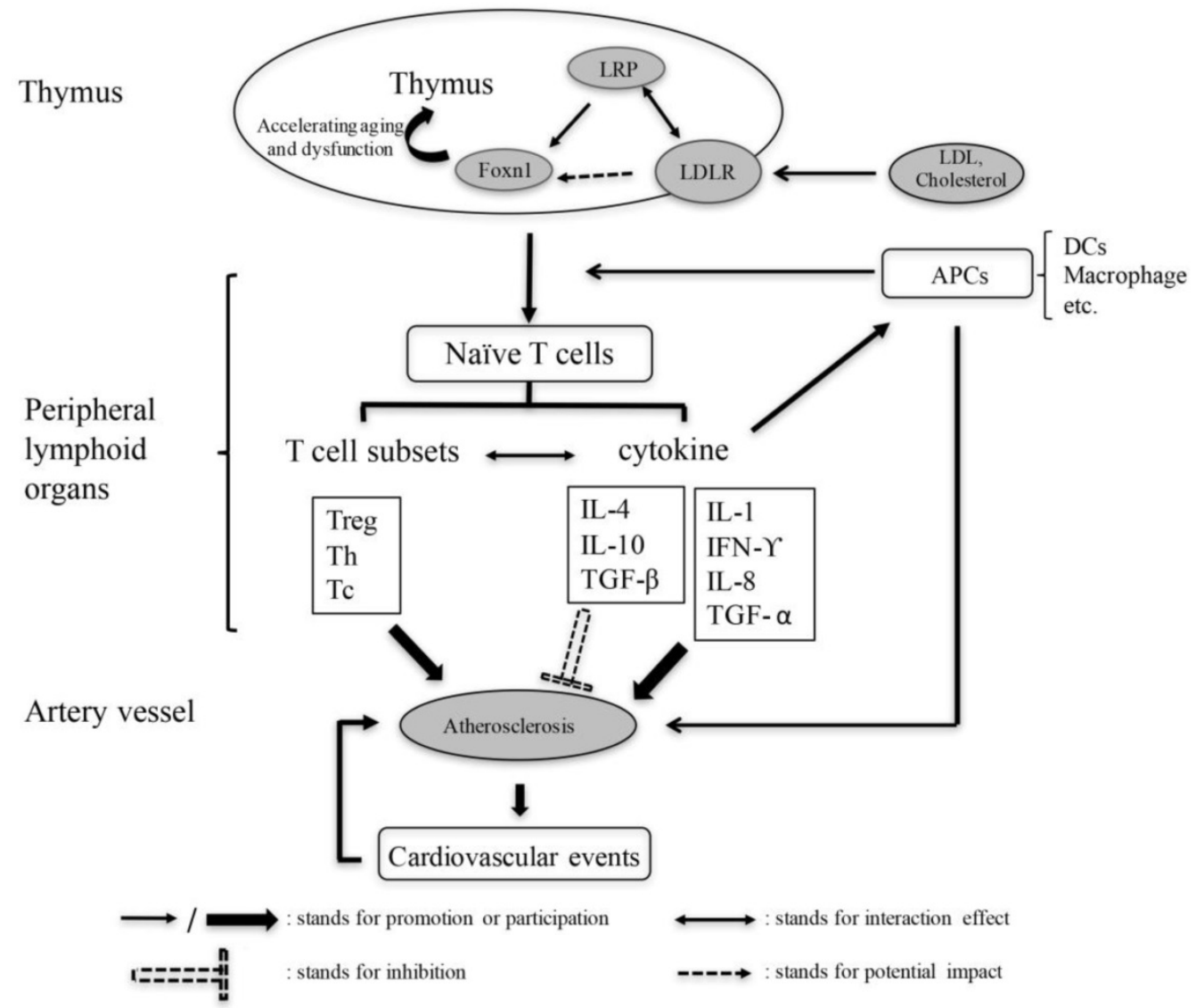

Figure 2. The pivotal role of thymus in AS mediated by immune and inflammatory response. Thymus dysfunction leads to the imbalance of T cell subsets and change in secretion of cytokines, thereby aggravating or inhibiting the progression of atherosclerosis, and as well as other cardiovascular events. LRP: Low density lipoprotein receptor-related proteins, LDLR: Low density lipoprotein receptors, APC: Antigen presenting cell, DC: Dendritic cell, Foxn 1: Forkhead box N1, Treg: Regulatory T-cell, Th: Helper T cell, Tc: Cytotoxic T cell. 


\section{Conclusion and perspective}

Atherosclerosis is considered as an immune inflammatory disease, and the $\mathrm{T}$ cell-mediated immune inflammatory response plays an important role in the pathogenesis of atherosclerosis[170]. T cells mature in the thymus site and are involved in the process of atherosclerosis induced by inflammation and immune response. Inflammatory mechanisms and immune system mechanisms are crucially involved in the pathophysiology of atherosclerosis and cardiovascular disease. $\mathrm{T}$ lymphocytes are involved and play an important role in both the inflammatory response and the immune response. An imbalance of the degree of activation of the protective Treg lymphocytes, the pro-inflammatory and cytotoxic macrophages and T-effector lymphocytes could thus be at the origin of the triggering or not of progression of vascular injury. However, all of these processes are closely associated with thymus function. In other words, changes in the function of thymus will be deeply affecting the process.

Based on previous research, we can speculate that the changes of thymus function may have an impact on the process of atherosclerosis. The mechanism of thymus involvement in the process of atherosclerosis is assumed as follows: Low density lipoprotein or cholesterol reduces the expression of the thymus transcription factor Foxn1 via low density lipoprotein receptors (LDLR) on the membrane surface and low density lipoprotein receptor-related proteins on the cell surface, which cause the thymus function decline or degradation. The imbalance of $\mathrm{T}$ cell subgroups and the decrease of naive $\mathrm{T}$ cells due to thymus dysfunction cause the increase or decrease in the secretion of various inflammatory factors, which in turn aggravates or inhibits atherosclerosis progression and cardiovascular events. NK T cell, DCs and macrophages can affect the process of atherosclerosis by affecting the production of naive $\mathrm{T}$ cells through the thymus. Furthermore, these cells can also participate in the progression of atherosclerosis via the direct secretion of cytokines or inducing other cells to secrete cytokines (Fig. 2).

According to our hypothesis, lentiviral transfection, siRNA, gene knockout and thymic transplantation technologies can be selected to improve aging thymus function in animal experiments. In the clinical treatment of atherosclerosis, and even other immune-related diseases, we may consider using a vaccine, or a similar alternative to foxn1 to improve the expression of foxn1 in the human body, thereby improving or restoring aging thymus function and resisting the related-diseases caused by the decline of immunity.
In summary, novel data increasingly suggests the potential for new targets of the thymus function for therapeutic intervention to modify the course and reduce events in atherosclerosis and cardiovascular disease, as studies increasingly implicate thymus-related mechanisms. Further investigation on changes of thymus function will help to develop new therapeutic targets that may improve outcomes in atherosclerosis and cardiovascular disease and discover novel approaches in the treatment of atherosclerosis and vascular disease.

Of course, the underlying mechanism of the hypothesis still has some shortcomings in this review. We also need to investigate that how low density lipoprotein affects the expression of the thymus transcription factor Foxn1 via low density lipoprotein receptors on the membrane surface and low density lipoprotein receptor-related proteins on the cell surface.

\section{Abbreviations}

Treg-cell/Tregs: Regulatory T-cell(s); Th: Helper T cells; Tc: Cytotoxic T cells; APC: Antigen presenting cell; DC: Dendritic cell; NK T: Natural killer T cells; Foxn1: Forkhead box N1; LDL: Low density lipoprotein; HDL: High density lipoprotein; LDLR: Low density lipoprotein receptors; LRP: Low density lipoprotein receptor-related proteins; vSMCs: Vascular smooth muscle cells; apoE: Apolipoprotein E; oxLDL: Oxidized LDL.

\section{Acknowledgements}

This work was supported by National Natural Science Foundation of China (81130065, 81072981, 30971101, 31171130, 30900528, 91539118), Shanghai Pujiang Talent Program (D-15), Shanghai Key Basic Research Program (10411956500), and Shanghai Project of International Cooperation and Exchange (10410701700).

\section{Authors' contributions}

Xianliang Dai, Zonggui $\mathrm{Wu}$ and Chun Liang conceived and designed the paper. Xianliang Dai, Danfeng Zhang and Chaoqun Wang analyzed the relevant literature and drew the figures. Xianliang Dai wrote the paper.

\section{Competing Interests}

The authors have declared that no competing interest exists.

\section{References}

1. Xue-Mei L, Jie C, Xuan D, et al. Changes in CD4+CD25+ Tregs in the pathogenesis of atherosclerosis in ApoE-/- mice. Exp Biol Med (Maywood). 2017;242(9):918-25. 
2. Chistiakov DA, Sobenin IA, Orekhov AN. Regulatory T cells in atherosclerosis and strategies to induce the endogenous atheroprotective immune response. Immunol Lett. 2013;151(1-2):10-22.

3. Sasaki N, Yamashita $\mathrm{T}$, Takeda M, Hirata $\mathrm{K}$. Regulatory $\mathrm{T}$ cells in atherogenesis. J Atheroscler Thromb. 2012;19(6):503-15

4. Galkina E, Ley K. Immune and inflammatory mechanisms of atherosclerosis $\left.{ }^{*}\right)$. Annu Rev Immunol. 2009;27:165-97.

5. Hansson GK, Libby P. The immune response in atherosclerosis: a double-edged sword. Nat Rev Immunol. 2006;6(7):508-19.

6. Fan J, Watanabe T. Inflammatory reactions in the pathogenesis of atherosclerosis. J Atheroscler Thromb. 2003;10(2):63-71.

7. Ross R. Atherosclerosis--an inflammatory disease. $N$ Engl J Med. 1999;340(2):115-26.

8. Meiler S, Smeets E, Winkels $\mathrm{H}$, et al. Constitutive GITR Activation Reduces Atherosclerosis by Promoting Regulatory CD4+ T-Cell Responses-Brief Report. Arterioscler Thromb Vasc Biol. 2016;36(9):1748-52.

9. Palmer S, Albergante L, Blackburn CC, Newman TJ. Thymic involution and rising disease incidence with age. Proc Natl Acad Sci U S A. 2018;115(8):1883-8.

10. Murray JM, Kaufmann GR, Hodgkin PD, et al. Naive T cells are maintained by thymic output in early ages but by proliferation without phenotypic change after age twenty. Immunol Cell Biol. 2003;81(6):487-95.

11. Lynch HE, Goldberg GL, Chidgey A, et al. Thymic involution and immune reconstitution. Trends Immunol. 2009;30(7):366-73.

12. Walters SN, Webster KE, Daley S, Grey ST. A role for intrathymic B cells in the generation of natural regulatory T cells. J Immunol. 2014;193(1):170-6.

13. Chmielewski V, Drupt F, Morfin R. Dexamethasone-induced apoptosis of mouse thymocytes: prevention by native 7alpha-hydroxysteroids. Immunol Cell Biol. 2000;78(3):238-46.

14. Ruan L, Zhang Z, Mu L, et al. Biological significance of FoxN1 gain-of-function mutations during $\mathrm{T}$ and $\mathrm{B}$ lymphopoiesis in juvenile mice. Cell Death Dis. 2014;5:e1457.

15. Hakim FT, Gress RE. Immunosenescence: deficits in adaptive immunity in the elderly. Tissue Antigens. 2007;70(3):179-89.

16. Brelinska R. Thymic epithelial cells in age-dependent involution. Microsc Res Tech. 2003;62(6):488-500

17. Shiraishi J, Utsuyama M, Seki S, et al. Essential microenvironment for thymopoiesis is preserved in human adult and aged thymus. Clin Dev Immunol. 2003;10(1):53-9.

18. Haynes BF, Markert ML, Sempowski GD, Patel DD, Hale LP. The role of the thymus in immune reconstitution in aging, bone marrow transplantation, and HIV-1 infection. Annu Rev Immunol. 2000;18:529-60.

19. Davies EG, Cheung M, Gilmour K, et al. Thymus transplantation for complete DiGeorge syndrome: European experience. J Allergy Clin Immunol. 2017.

20. Ikehara S, Li M. Stem cell transplantation improves aging-related diseases. Front Cell Dev Biol. 2014:2:16.

21. Markert ML, Boeck A, Hale LP, et al. Transplantation of thymus tissue in complete DiGeorge syndrome. N Engl J Med. 1999;341(16):1180-9.

22. Hosaka N, Nose M, Kyogoku M, et al. Thymus transplantation, a critical factor for correction of autoimmune disease in aging MRL/+mice. Proc Natl Acad Sci U S A. 1996;93(16):8558-62.

23. Echeverri Tirado LC, Yassin LM. B cells interactions in lipid immune responses: implications in atherosclerotic disease. Lipids Health Dis. 2017;16(1):30.

24. Roshan MH, Tambo A, Pace NP. The Role of TLR2, TLR4, and TLR9 in the Pathogenesis of Atherosclerosis. Int J Inflam. 2016;2016:1532832.

25. Gu HF, Tang CK, Yang YZ. Psychological stress, immune response, and atherosclerosis. Atherosclerosis. 2012;223(1):69-77.

26. Huang S, Ding R, Lin Y, et al. Reduced T-Cell Thymic Export Reflected by sj-TREC in Patients with Coronary Artery Disease. J Atheroscler Thromb. 2016;23(5):632-43.

27. Bento-de-Souza L, Victor JR, Bento-de-Souza LC, et al. Constitutive expression of genes encoding notch receptors and ligands in developing lymphocytes, nTreg cells and dendritic cells in the human thymus. Results Immunol. 2016;6:15-20

28. Plum J, De Smedt M, Leclercq G, et al. Human intrathymic development: a selective approach. Semin Immunopathol. 2008;30(4):411-23.

29. $\mathrm{Hu} \mathrm{Z}$, Lancaster JN, Sasiponganan C, Ehrlich LI. CCR4 promotes medullary entry and thymocyte-dendritic cell interactions required for central tolerance. J Exp Med. 2015;212(11):1947-65.

30. Hu Z, Lancaster JN, Ehrlich LI. The Contribution of Chemokines and Migration to the Induction of Central Tolerance in the Thymus. Front Immunol. 2015;6:398

31. Love PE, Bhandoola A. Signal integration and crosstalk during thymocyte migration and emigration. Nat Rev Immunol. 2011;11(7):469-77.

32. Richards DM, Delacher M, Goldfarb Y, et al. Treg Cell Differentiation: From Thymus to Peripheral Tissue. Prog Mol Biol Transl Sci. 2015;136:175-205.

33. Abbas AK, Benoist C, Bluestone JA, et al. Regulatory T cells: recommendations to simplify the nomenclature. Nat Immunol. 2013;14(4):307-8.

34. Groves AM, Johnston CJ, Misra RS, Williams JP, Finkelstein JN. Effects of IL-4 on Pulmonary Fibrosis and the Accumulation and Phenotype of Macrophage Subpopulations Following Thoracic Irradiation. Int J Radiat Biol. 2016:1-36.

35. Francos-Quijorna I, Amo-Aparicio J, Martinez-Muriana A, Lopez-Vales R. IL-4 drives microglia and macrophages toward a phenotype conducive for tissue repair and functional recovery after spinal cord injury. Glia. 2016.
36. Czimmerer $\mathrm{Z}$, Varga $\mathrm{T}$, Kiss $\mathrm{M}$, et al. The IL-4/STAT6 signaling axis establishes a conserved microRNA signature in human and mouse macrophages regulating cell survival via miR-342-3p. Genome Med. 2016;8(1):63

37. Miossec P, Korn T, Kuchroo VK. Interleukin- 17 and type 17 helper T cells. $\mathrm{N}$ Engl J Med. 2009;361(9):888-98.

38. Veldhoen M, Hocking RJ, Atkins CJ, Locksley RM, Stockinger B. TGFbeta in the context of an inflammatory cytokine milieu supports de novo differentiation of IL-17-producing T cells. Immunity. 2006;24(2):179-89.

39. Mangan PR, Harrington LE, O'Quinn DB, et al. Transforming growth factor-beta induces development of the $\mathrm{T}(\mathrm{H}) 17$ lineage. Nature. 2006;441(7090):231-4

40. Ivanov, II, McKenzie BS, Zhou L, et al. The orphan nuclear receptor RORgammat directs the differentiation program of proinflammatory IL-17+ T helper cells. Cell. 2006;126(6):1121-33.

41. Kolls JK, Linden A. Interleukin-17 family members and inflammation. Immunity. 2004;21(4):467-76.

42. Mazidi M, Penson P, Gluba-Brzozka A, Rysz J, Banach M. Relationship between long noncoding RNAs and physiological risk factors of cardiovascular disease. J Clin Lipidol. 2017.

43. Kaur J. A comprehensive review on metabolic syndrome. Cardiol Res Pract. 2014;2014:943162.

44. Ragab SM, Safan MA, Obeid OM, Sherief AS. Lipoprotein-associated phospholipase A2 (Lp-PLA2) and tumor necrosis factor-alpha (TNF-alpha) and their relation to premature atherosclerosis in beta-thalassemia children. Hematology. 2015;20(4):228-38.

45. Zhang Y, Yang X, Bian F, et al. TNF-alpha promotes early atherosclerosis by increasing transcytosis of LDL across endothelial cells: crosstalk between NF-kappaB and PPAR-gamma. J Mol Cell Cardiol. 2014;72:85-94.

46. Ito S, Iwaki S, Kondo R, et al. TNF-alpha production in NKT cell hybridoma is regulated by sphingosine-1-phosphate: implications for inflammation in atherosclerosis. Coron Artery Dis. 2014;25(4):311-20.

47. Klinghammer L, Urschel K, Cicha I, et al. Impact of telmisartan on the inflammatory state in patients with coronary atherosclerosis--influence on IP-10, TNF-alpha and MCP-1. Cytokine. 2013;62(2):290-6.

48. Puz P, Lasek-Bal A, Ziaja D, Kazibutowska Z, Ziaja K. Inflammatory markers in patients with internal carotid artery stenosis. Arch Med Sci. 2013;9(2):254-60.

49. Xiao N, Yin M, Zhang L, et al. Tumor necrosis factor-alpha deficiency retards early fatty-streak lesion by influencing the expression of inflammatory factors in apoE-null mice. Mol Genet Metab. 2009;96(4):239-44.

50. Willerson JT, Ridker PM. Inflammation as a cardiovascular risk factor. Circulation. 2004;109(21 Suppl 1):II2-10.

51. Steverson D, Jr., Tian L, Fu Y, et al. Tribbles Homolog 3 Promotes Foam Cell Formation Associated with Decreased Proinflammatory Cytokine Production in Macrophages: Evidence for Reciprocal Regulation of Cholesterol Uptake and Inflammation. Metab Syndr Relat Disord. 2016;14(1):7-15.

52. Rader DJ. IL-1 and atherosclerosis: a murine twist to an evolving human story. J Clin Invest. 2012;122(1):27-30.

53. Dinarello CA. A clinical perspective of IL-1beta as the gatekeeper of inflammation. Eur J Immunol. 2011;41(5):1203-17.

54. Marino F, Tozzi M, Schembri L, et al. Production of IL-8, VEGF and Elastase by Circulating and Intraplaque Neutrophils in Patients with Carotid Atherosclerosis. PLoS One. 2015;10(4):e0124565.

55. Marino F, Guasti L, Tozzi M et al. Angiotensin type 1 receptor expression and interleukin-8 production in polymorphonuclear leukocytes of patients with peripheral arterial disease. J Cardiovasc Pharmacol. 2009;54(6):520-5.

56. Guasti L, Marino F, Cosentino M, et al. Prolonged statin-associated reduction in neutrophil reactive oxygen species and angiotensin II type 1 receptor expression: 1-year follow-up. Eur Heart J. 2008;29(9):1118-26.

57. Guasti L, Marino F, Cosentino M, et al. Simvastatin treatment modifies polymorphonuclear leukocyte function in high-risk individuals: a longitudinal study. J Hypertens. 2006;24(12):2423-30.

58. Boisvert WA. The participation of chemokines in atherosclerosis. Discov Med. 2004;4(23):288-92.

59. Zykov MV, Barbarash OL, Kashtalap VV, Kutikhin AG, Barbarash LS. Interleukin-12 serum level has prognostic value in patients with ST-segment elevation myocardial infarction. Heart Lung. 2016;45(4):336-40.

60. Zhang $X$, Niessner A, Nakajima $T$, et al. Interleukin 12 induces T-cell recruitment into the atherosclerotic plaque. Circ Res. 2006;98(4):524-31.

61. Davenport P, Tipping PG. The role of interleukin-4 and interleukin- 12 in the progression of atherosclerosis in apolipoprotein E-deficient mice. Am J Pathol. 2003;163(3):1117-25.

62. Lee TS, Yen HC, Pan CC, Chau LY. The role of interleukin 12 in the development of atherosclerosis in ApoE-deficient mice. Arterioscler Thromb Vasc Biol. 1999:19(3):734-42.

63. Su Z, Lu H, Jiang H, et al. IFN-gamma-producing Th17 cells bias by HMGB1-T-bet/RUNX3 axis might contribute to progression of coronary artery atherosclerosis. Atherosclerosis. 2015;243(2):421-8.

64. Kasahara K, Sasaki N, Yamashita T, et al. CD3 antibody and IL-2 complex combination therapy inhibits atherosclerosis by augmenting a regulatory immune response. J Am Heart Assoc. 2014;3(2):e000719.

65. Gupta S, Pablo AM, Jiang $X$, et al. IFN-gamma potentiates atherosclerosis in ApoE knock-out mice. J Clin Invest. 1997;99(11):2752-61. 
66. Caligiuri G, Rudling $\mathrm{M}$, Ollivier $\mathrm{V}$, et al. Interleukin-10 deficiency increases atherosclerosis, thrombosis, and low-density lipoproteins in apolipoprotein $\mathrm{E}$ knockout mice. Mol Med. 2003;9(1-2):10-7.

67. Lutgens E, Gijbels M, Smook M, et al. Transforming growth factor-beta mediates balance between inflammation and fibrosis during plaque progression. Arterioscler Thromb Vasc Biol. 2002;22(6):975-82.

68. Mallat Z, Gojova A, Marchiol-Fournigault C, et al. Inhibition of transforming growth factor-beta signaling accelerates atherosclerosis and induces an unstable plaque phenotype in mice. Circ Res. 2001;89(10):930-4.

69. Grainger DJ, Mosedale DE, Metcalfe JC, Bottinger EP. Dietary fat and reduced levels of TGFbeta1 act synergistically to promote activation of the vascular endothelium and formation of lipid lesions. J Cell Sci. 2000;113 ( Pt 13):2355-61.

70. Zhao XN, Li YN, Wang YT. Interleukin-4 regulates macrophage polarization via the MAPK signaling pathway to protect against atherosclerosis. Genet Mol Res. 2016;15(1).

71. King VL, Szilvassy SJ, Daugherty A. Interleukin-4 deficiency decreases atherosclerotic lesion formation in a site-specific manner in female LDL receptor-/- mice. Arterioscler Thromb Vasc Biol. 2002;22(3):456-61.

72. Pinderski LJ, Fischbein MP, Subbanagounder G, et al. Overexpression of interleukin-10 by activated $\mathrm{T}$ lymphocytes inhibits atherosclerosis in LDL receptor-deficient Mice by altering lymphocyte and macrophage phenotypes. Circ Res. 2002;90(10):1064-71.

73. Potteaux S, Esposito B, van Oostrom O, et al. Leukocyte-derived interleukin 10 is required for protection against atherosclerosis in low-density lipoprotein receptor knockout mice. Arterioscler Thromb Vasc Biol. 2004;24(8):1474-8.

74. Mallat Z, Besnard S, Duriez M, et al. Protective role of interleukin-10 in atherosclerosis. Circ Res. 1999;85(8):e17-24.

75. Pinderski Oslund LJ, Hedrick CC, Olvera T, et al. Interleukin-10 blocks atherosclerotic events in vitro and in vivo. Arterioscler Thromb Vasc Biol. 1999;19(12):2847-53.

76. Pedersen BK. Anti-inflammatory effects of exercise: role in diabetes and cardiovascular disease. Eur J Clin Invest. 2017;47(8):600-11.

77. Schieffer B, Selle T, Hilfiker A, et al. Impact of interleukin-6 on plaque development and morphology in experimental atherosclerosis. Circulation. 2004;110(22):3493-500.

78. Van Lenten BJ, Wagner AC, Navab M, Fogelman AM. Oxidized phospholipids induce changes in hepatic paraoxonase and ApoJ but not monocyte chemoattractant protein-1 via interleukin-6. J Biol Chem. 2001;276(3):1923-9.

79. Dinh TN, Kyaw TS, Kanellakis $P$, et al. Cytokine therapy with interleukin-2/anti-interleukin-2 monoclonal antibody complexes expands CD4+CD25+Foxp3+ regulatory $\mathrm{T}$ cells and attenuates development and progression of atherosclerosis. Circulation. 2012;126(10):1256-66.

80. Dietrich T, Hucko T, Schneemann C, et al. Local delivery of IL-2 reduces atherosclerosis via expansion of regulatory $\mathrm{T}$ cells. Atherosclerosis. 2012;220(2):329-36.

81. Foks AC, Frodermann V, ter Borg M, et al. Differential effects of regulatory $\mathrm{T}$ cells on the initiation and regression of atherosclerosis. Atherosclerosis. 2011;218(1):53-60.

82. Lin J, Yang L, Silva HM, et al. Increased generation of Foxp3(+) regulatory $\mathrm{T}$ cells by manipulating antigen presentation in the thymus. Nat Commun. 2016;7:10562.

83. Wing $\mathrm{K}$, Sakaguchi $\mathrm{S}$. Regulatory $\mathrm{T}$ cells exert checks and balances on self tolerance and autoimmunity. Nat Immunol. 2010;11(1):7-13.

84. Mellanby RJ, Thomas DC, Lamb J. Role of regulatory T-cells in autoimmunity. Clin Sci (Lond). 2009:116(8):639-49.

85. Piccirillo CA, d'Hennezel E, Sgouroudis E, Yurchenko E. CD4+Foxp3+ regulatory $\mathrm{T}$ cells in the control of autoimmunity: in vivo veritas. Curr Opin Immunol. 2008;20(6):655-62.

86. Lam RS, O'Brien-Simpson NM, Holden JA, et al. Unprimed, M1 and M2 Macrophages Differentially Interact with Porphyromonas gingivalis. PLoS One. 2016;11(7):e0158629.

87. Gordon $\mathrm{S}$. The role of the macrophage in immune regulation. Res Immunol. 1998;149(7-8):685-8.

88. Rosenthal AS. Regulation of the immune response--role of the macrophage. $\mathrm{N}$ Engl J Med. 1980;303(20):1153-6.

89. Oh J, Shin JS. The Role of Dendritic Cells in Central Tolerance. Immune Netw. 2015;15(3):111-20.

90. Goldschneider I, Cone RE. A central role for peripheral dendritic cells in the induction of acquired thymic tolerance. Trends Immunol. 2003;24(2):77-81.

91. Mellman I, Steinman RM. Dendritic cells: specialized and regulated antigen processing machines. Cell. 2001;106(3):255-8.

92. Gerrity RG, Naito HK, Richardson M, Schwartz CJ. Dietary induced atherogenesis in swine. Morphology of the intima in prelesion stages. Am J Pathol. 1979;95(3):775-92

93. Mallat $\mathrm{Z}$, Taleb S, Ait-Oufella $\mathrm{H}$, Tedgui A. The role of adaptive $\mathrm{T}$ cell immunity in atherosclerosis. J Lipid Res. 2009;50 Suppl:S364-9.

94. Taleb S, Tedgui A, Mallat Z. Regulatory T-cell immunity and its relevance to atherosclerosis. J Intern Med. 2008;263(5):489-99.

95. Mor A, Planer D, Luboshits G, et al. Role of naturally occurring CD4+ CD25+ regulatory $\mathrm{T}$ cells in experimental atherosclerosis. Arterioscler Thromb Vasc Biol. 2007;27(4):893-900.

96. Mallat Z, Ait-Oufella H, Tedgui A. Regulatory T-cell immunity in atherosclerosis. Trends Cardiovasc Med. 2007:17(4):113-8.

97. Ait-Oufella H, Salomon BL, Potteaux S, et al. Natural regulatory T cells control the development of atherosclerosis in mice. Nat Med. 2006;12(2):178-80.
98. Mallat $\mathrm{Z}$, Ait-Oufella $\mathrm{H}$, Tedgui A. Regulatory $\mathrm{T}$ cell responses: potential role in the control of atherosclerosis. Curr Opin Lipidol. 2005;16(5):518-24.

99. Peterson RA. Regulatory T-cells: diverse phenotypes integral to immune homeostasis and suppression. Toxicol Pathol. 2012;40(2):186-204.

100. Sasaki N, Yamashita T, Takeda M, et al. Oral anti-CD3 antibody treatment induces regulatory $\mathrm{T}$ cells and inhibits the development of atherosclerosis in mice. Circulation. 2009;120(20):1996-2005.

101. Gotsman I, Grabie N, Gupta R, et al. Impaired regulatory T-cell response and enhanced atherosclerosis in the absence of inducible costimulatory molecule. Circulation. 2006;114(19):2047-55

102. Mallat $\mathrm{Z}$, Gojova A, Brun V, et al. Induction of a regulatory $\mathrm{T}$ cell type 1 response reduces the development of atherosclerosis in apolipoprotein E-knockout mice. Circulation. 2003;108(10):1232-7.

103. Wick G, Grubeck-Loebenstein B. Primary and secondary alterations of immune reactivity in the elderly: impact of dietary factors and disease. Immunol Rev. 1997;160:171-84.

104. Klingenberg R, Lebens M, Hermansson A, et al. Intranasal immunization with an apolipoprotein B-100 fusion protein induces antigen-specific regulatory $\mathrm{T}$ cells and reduces atherosclerosis. Arterioscler Thromb Vasc Biol. 2010;30(5):946-52.

105. Eid RE, Rao DA, Zhou J, et al. Interleukin-17 and interferon-gamma are produced concomitantly by human coronary artery-infiltrating $\mathrm{T}$ cells and act synergistically on vascular smooth muscle cells. Circulation. 2009;119(10):1424-32.

106. Zhou X, Johnston TP, Johansson D, et al. Hypercholesterolemia leads to elevated TGF-beta1 activity and T helper 3-dependent autoimmune responses in atherosclerotic mice. Atherosclerosis. 2009;204(2):381-7.

107. Methe H, Brunner S, Wiegand D, et al. Enhanced T-helper-1 lymphocyte activation patterns in acute coronary syndromes. J Am Coll Cardiol. 2005;45(12):1939-45.

108. Frostegard J, Ulfgren AK, Nyberg P, et al. Cytokine expression in advanced human atherosclerotic plaques: dominance of pro-inflammatory (Th1) and macrophage-stimulating cytokines. Atherosclerosis. 1999;145(1):33-43.

109. Wang K, Jin F, Zhang Z, Sun X. Angiotensin II Promotes the Development of Carotid Atherosclerosis in Type 2 Diabetes Patients via Regulating the T Cells Activities: A Cohort Study. Med Sci Monit. 2016;22:4000-8.

110. Ait-Oufella $\mathrm{H}$, Taleb S, Mallat $Z$, Tedgui A. Cytokine network and $\mathrm{T}$ cell immunity in atherosclerosis. Semin Immunopathol. 2009;31(1):23-33.

111. Hasib L, Lundberg AK, Zachrisson H, Ernerudh J, Jonasson L. Functional and homeostatic defects of regulatory $\mathrm{T}$ cells in patients with coronary artery disease. J Intern Med. 2016;279(1):63-77.

112. Spitz C, Winkels H, Burger C, et al. Regulatory $\mathrm{T}$ cells in atherosclerosis: critical immune regulatory function and therapeutic potential. Cell Mol Life Sci. 2016;73(5):901-22.

113. Thornton AM, Shevach EM. CD4+CD25+ immunoregulatory T cells suppress polyclonal $\mathrm{T}$ cell activation in vitro by inhibiting interleukin 2 production. J Exp Med. 1998;188(2):287-96.

114. Xie JJ, Wang J, Tang TT, et al. The Th17/Treg functional imbalance during atherogenesis in ApoE(-/-) mice. Cytokine. 2010;49(2):185-93.

115. van Olffen RW, Koning N, van Gisbergen KP, et al. GITR triggering induces expansion of both effector and regulatory CD4+ T cells in vivo. J Immunol. 2009;182(12):7490-500.

116. Gotsman I, Sharpe AH, Lichtman AH. T-cell costimulation and coinhibition in atherosclerosis. Circ Res. 2008;103(11):1220-31.

117. Ziegler SF. FOXP3: of mice and men. Annu Rev Immunol. 2006:24:209-26.

118. Sakaguchi S, Sakaguchi N, Asano M, Itoh M, Toda M. Immunologic self-tolerance maintained by activated $\mathrm{T}$ cells expressing IL-2 receptor alpha-chains (CD25). Breakdown of a single mechanism of self-tolerance causes various autoimmune diseases. J Immunol. 1995;155(3):1151-64.

119. Belizario JE, Brandao W, Rossato C, Peron JP. Thymic and Postthymic Regulation of Naive CD4(+) T-Cell Lineage Fates in Humans and Mice Models. Mediators Inflamm. 2016;2016:9523628.

120. Macritchie N, Grassia G, Sabir SR, et al. Plasmacytoid dendritic cells play a key role in promoting atherosclerosis in apolipoprotein E-deficient mice. Arterioscler Thromb Vasc Biol. 2012;32(11):2569-79.

121. Coombes JL, Powrie F. Dendritic cells in intestinal immune regulation. Nat Rev Immunol. 2008;8(6):435-46

122. Atarashi $\mathrm{K}$, Nishimura J, Shima $\mathrm{T}$, et al. ATP drives lamina propria $\mathrm{T}(\mathrm{H}) 17$ cell differentiation. Nature. 2008;455(7214):808-12.

123. Sun CM, Hall JA, Blank RB, et al. Small intestine lamina propria dendritic cells promote de novo generation of Foxp3 T reg cells via retinoic acid. J Exp Med. 2007;204(8):1775-85.

124. Valero J, Bernardino L, Cardoso F, et al. Impact of Neuroinflammation on Hippocampal Neurogenesis: Relevance to Aging and Alzheimer's Disease. J Alzheimers Dis. 2017.

125. Caruso C, Lio D, Cavallone L, Franceschi C. Aging, longevity, inflammation, and cancer. Ann N Y Acad Sci. 2004;1028:1-13.

126. Pawelec G, Barnett $Y$, Forsey R, et al. T cells and aging, January 2002 update. Front Biosci. 2002;7:d1056-183.

127. Bruunsgaard $H$, Pedersen $M$, Pedersen BK. Aging and proinflammatory cytokines. Curr Opin Hematol. 2001;8(3):131-6.

128. Franceschi $C$, Bonafe $M$, Valensin $S$, et al. Inflamm-aging. An evolutionary perspective on immunosenescence. Ann N Y Acad Sci. 2000;908:244-54.

129. Brod SA. Unregulated inflammation shortens human functional longevity. Inflamm Res. 2000;49(11):561-70. 
130. Zhao L, Sun L, Wang H, et al. Changes of CD4+CD25+Foxp3+ regulatory $\mathrm{T}$ cells in aged Balb/c mice. J Leukoc Biol. 2007;81(6):1386-94.

131. Hakim FT, Memon SA, Cepeda R, et al. Age-dependent incidence, time course, and consequences of thymic renewal in adults. J Clin Invest. 2005;115(4):930-9.

132. Taams LS, Akbar AN. Peripheral generation and function of CD4+CD25+ regulatory T cells. Curr Top Microbiol Immunol. 2005;293:115-31.

133. Tsaknaridis L, Spencer L, Culbertson N, et al. Functional assay for human CD4+CD25+ Treg cells reveals an age-dependent loss of suppressive activity. J Neurosci Res. 2003;74(2):296-308.

134. Almeida AR, Borghans JA, Freitas AA. T cell homeostasis: thymus regeneration and peripheral $\mathrm{T}$ cell restoration in mice with a reduced fraction of competent precursors. J Exp Med. 2001;194(5):591-9.

135. Haynes L, Eaton SM, Burns EM, Randall TD, Swain SL. Newly generated CD4 $\mathrm{T}$ cells in aged animals do not exhibit age-related defects in response to antigen. J Exp Med. 2005;201(6):845-51.

136. Dion ML, Poulin JF, Bordi R, et al. HIV infection rapidly induces and maintains a substantial suppression of thymocyte proliferation. Immunity. 2004;21(6):757-68.

137. Guo J, Feng Y, Barnes P, et al. Deletion of FoxN1 in the thymic medullary epithelium reduces peripheral $\mathrm{T}$ cell responses to infection and mimics changes of aging. PLoS One. 2012;7(4):e34681.

138. Chidgey A, Dudakov J, Seach N, Boyd R. Impact of niche aging on thymic regeneration and immune reconstitution. Semin Immunol. 2007;19(5):331-40.

139. Taub DD, Longo DL. Insights into thymic aging and regeneration. Immunol Rev. 2005;205:72-93.

140. Fry TJ, Mackall CL. Current concepts of thymic aging. Springer Semin Immunopathol. 2002;24(1):7-22

141. Zook EC, Krishack PA, Zhang S, et al. Overexpression of Foxn1 attenuates age-associated thymic involution and prevents the expansion of peripheral CD4 memory T cells. Blood. 2011;118(22):5723-31.

142. Swain S, Clise-Dwyer K, Haynes L. Homeostasis and the age-associated defect of CD4 T cells. Semin Immunol. 2005;17(5):370-7.

143. Stutman O, Good RA. Duration of thymic function. Ser Haematol. 1974;7(4):505-23.

144. Thoman ML. The pattern of T lymphocyte differentiation is altered during thymic involution. Mech Ageing Dev. 1995;82(2-3):155-70.

145. Ortman CL, Dittmar KA, Witte PL, Le PT. Molecular characterization of the mouse involuted thymus: aberrations in expression of transcription regulators in thymocyte and epithelial compartments. Int Immunol. 2002;14(7):813-22.

146. Bredenkamp N, Nowell CS, Blackburn CC. Regeneration of the aged thymus by a single transcription factor. Development. 2014;141(8):1627-37.

147. Zuklys S, Handel A, Zhanybekova S, et al. Foxn1 regulates key target genes essential for $\mathrm{T}$ cell development in postnatal thymic epithelial cells. Nat Immunol. 2016.

148. Newton $\mathrm{AH}$, Benedict $\mathrm{SH}$. Low density lipoprotein promotes human naive $\mathrm{T}$ cell differentiation to Th1 cells. Hum Immunol. 2014;75(7):621-8.

149. Shih PT, Elices MJ, Fang ZT, et al. Minimally modified low-density lipoprotein induces monocyte adhesion to endothelial connecting segment- 1 by activating beta1 integrin. J Clin Invest. 1999;103(5):613-25.

150. McMurray HF, Parthasarathy S, Steinberg D. Oxidatively modified low density lipoprotein is a chemoattractant for human $\mathrm{T}$ lymphocytes. J Clin Invest. 1993;92(2):1004-8.

151. Cushing SD, Berliner JA, Valente AJ, et al. Minimally modified low density lipoprotein induces monocyte chemotactic protein 1 in human endothelial cells and smooth muscle cells. Proc Natl Acad Sci U S A. 1990;87(13):5134-8.

152. Berliner JA, Territo MC, Sevanian A, et al. Minimally modified low density lipoprotein stimulates monocyte endothelial interactions. J Clin Invest. 1990;85(4):1260-6

153. Laudati E, Gilder AS, Lam MS, et al. The activities of LDL Receptor-related Protein-1 (LRP1) compartmentalize into distinct plasma membrane microdomains. Mol Cell Neurosci. 2016;76:42-51.

154. Lillis AP, Muratoglu SC, Au DT, et al. LDL Receptor-Related Protein-1 (LRP1) Regulates Cholesterol Accumulation in Macrophages. PLoS One. 2015;10(6):e0128903.

155. Strickland DK, Ashcom JD, Williams S, et al. Sequence identity between the alpha 2-macroglobulin receptor and low density lipoprotein receptor-related protein suggests that this molecule is a multifunctional receptor. J Biol Chem. 1990;265(29):17401-4.

156. Herz J, Hamann U, Rogne S, et al. Surface location and high affinity for calcium of a 500-kd liver membrane protein closely related to the LDL-receptor suggest a physiological role as lipoprotein receptor. EMBO J. 1988;7(13):4119-27.

157. Yancey PG, Ding Y, Fan D, et al. Low-density lipoprotein receptor-related protein 1 prevents early atherosclerosis by limiting lesional apoptosis and inflammatory Ly-6Chigh monocytosis: evidence that the effects are not apolipoprotein E dependent. Circulation. 2011;124(4):454-64.

158. Yancey PG, Blakemore J, Ding L, et al. Macrophage LRP-1 controls plaque cellularity by regulating efferocytosis and Akt activation. Arterioscler Thromb Vasc Biol. 2010;30(4):787-95.

159. Overton CD, Yancey PG, Major AS, Linton MF, Fazio S. Deletion of macrophage LDL receptor-related protein increases atherogenesis in the mouse. Circ Res. 2007;100(5):670-7.

160. Hu L, Boesten LS, May P, et al. Macrophage low-density lipoprotein receptor-related protein deficiency enhances atherosclerosis in ApoE/LDLR double knockout mice. Arterioscler Thromb Vasc Biol. 2006;26(12):2710-5.
161. Boukais K, Bayles R, Borges Lde F, et al. Uptake of Plasmin-PN-1 Complexes in Early Human Atheroma. Front Physiol. 2016;7:273

162. Boucher P, Li WP, Matz RL, et al. LRP1 functions as an atheroprotective integrator of TGFbeta and PDFG signals in the vascular wall: implications for Marfan syndrome. PLoS One. 2007;2(5):e448

163. Boucher P, Gotthardt M, Li WP, Anderson RG, Herz J. LRP: role in vascular wall integrity and protection from atherosclerosis. Science. 2003;300(5617):329-32.

164. Strickland DK, Au DT, Cunfer P, Muratoglu SC. Low-density lipoprotein receptor-related protein-1: role in the regulation of vascular integrity. Arterioscler Thromb Vasc Biol. 2014;34(3):487-98.

165. Muratoglu SC, Belgrave S, Lillis AP, et al. Macrophage LRP1 suppresses neo-intima formation during vascular remodeling by modulating the TGF-beta signaling pathway. PLoS One. 2011;6(12):e28846.

166. Emonard H, Theret L, Bennasroune AH, Dedieu S. Regulation of LRP-1 expression: make the point. Pathol Biol (Paris). 2014;62(2):84-90.

167. Llorente-Cortes $\mathrm{V}$, Royo $\mathrm{T}$, Juan-Babot $\mathrm{O}$, Badimon L. Adipocyte differentiation-related protein is induced by LRP1-mediated aggregated LDL internalization in human vascular smooth muscle cells and macrophages. J Lipid Res. 2007;48(10):2133-40.

168. Llorente-Cortes V, Royo T, Otero-Vinas M, Berrozpe M, Badimon L. Sterol regulatory element binding proteins downregulate LDL receptor-related protein (LRP1) expression and LRP1-mediated aggregated LDL uptake by human macrophages. Cardiovasc Res. 2007;74(3):526-36.

169. Llorente-Cortes V, Otero-Vinas M, Camino-Lopez S, Costales P, Badimon L. Cholesteryl esters of aggregated LDL are internalized by selective uptake in human vascular smooth muscle cells. Arterioscler Thromb Vasc Biol. 2006;26(1):117-23.

170. Lusis AJ. Atherosclerosis. Nature. 2000;407(6801):233-41. 